\title{
DECAY AND TERMITE RESISTANCE OF PARTICLEBOARD MANUFACTURED FROM WOOD, BAMBOO AND RICE HUSK
}

\author{
Rafael Rodolfo de Melo ${ }^{1, \AA}$, Diego Martins Stangerlin ${ }^{1}$, \\ Ricardo Robinson Campomanes Santana ${ }^{2}$, Talita Dantas Pedrosa ${ }^{3}$
}

\begin{abstract}
The resistance of particleboards, made from wood, bamboo and rice husk, to fungi and termites was evaluated. Panels were composed of 100\% wood (Eucalyptus grandis), 100\% bamboo (Bambusa vulgaris), $100 \%$ rice husk (Oryza sativa), 50\% wood and 50\% bamboo; and 50\% wood and 50\% rice husk. Panels exposed to the decay the brown-rot fungus (Gloeophyllum trabeum and the white-rot fungus (Trametes versicolor), and, in a choice feeding trial, to termites (Nasutitermes corniger). The rice husk particleboards had the highest resistance of all samples and the bamboo particleboards had the lowest resistance. $T$. versicolor fungi produced a larger mass loss in the particleboards than did G. trabeum.
\end{abstract}

Keywords: Agricultural residues, Bambusa vulgaris, biodeterioration, decay susceptibly index, Eucalyptus grandis, Oryza sativa.

\section{INTRODUCTION}

Wood particleboards, as well as solid wood, when utilized in places with high moisture conditions, are subject to deterioration and, once attacked, they lose both weight and mechanical resistance. Apart from moisture, Zabel and Morrell (1992) emphasize that other factors such as temperature, $\mathrm{pH}$ and oxygen have an influence on the capacity of xylophagous agents to colonize and, consequently, deteriorate any lignocellulosic material.

The wood used for particleboard manufacturing usually is of low durability. The utilization of wood with higher durability or the combination of species to improving its resistance to biological agents has been studied by some authors (Evans et al. 1997, Kartal and Green 2003, Shi et al. 2006, Okino 2007). Nevertheless, not much is known about combining wood particles with alternative raw materials in particleboard manufacturing. Yalinkilic et al. (1998) consider that the utilization of raw materials with greater durability for composites manufacturing would decrease environmental and health risks caused by the application of chemical preservatives.

The particleboards can be produced from any lignocellulosic materials, as long as they provide proper physical, mechanical and biological resistance. The quality of the final product is directly related to the choice of material. Within the alternative sources that have been used or with potential for utilization, bamboo and rice husk can be pointed out. Their utilization can be an alternative for regions with scarce wood resources, or even as a way to decrease the final cost of particleboards.

\footnotetext{
${ }^{1}$ Forest Engineer, Teacher, Doctor in Wood Science and Technology, Mato Grosso Federal University (UFMT),

Agricultural and Environment Science Institute (ICAA), Sinop, MT, Brazil. diego_stangerlin@yahoo.com.br.

${ }^{2}$ Physical, Teacher, Doctor in Physical, Mato Grosso Federal University (UFMT), Agricultural and Environment Science Institute (ICAA),

Sinop, MT, Brazil. ricardo_speru@yahoo.com.br.

${ }^{3}$ Environmental Engineer, Campina Grande Federal University (UFCG), Department of Environmental Engineering, Pombal, PB, Brazil. tdpedrosa2@yahoo.com.br.

Received: 16.08. 2013 Accepted: 17.03. 2014

^Corresponding author: rrmelo2@yahoo.com.br.
} 
With respect to the physical-mechanical properties, some studies indicated that particleboards made from bamboo, on its own or combined with wood particles, give satisfactory performance (Hiziroglu et al. 2005, Araujo et al. 2011). On the other hand, one of its inconveniences drawbacks is its fast deterioration due to the anatomical structure composed of fibrovascular bundles surrounded by parenchymal tissue, rich in reserve substances in the form of starch (Stangerlin et al. 2011). Yet, an inverse behavior has been observed for rice husk (Lee and Kang 1998, Melo et al. 2010). Therefore, in the present study the resistance of particleboards manufactured from wood, rice husk and bamboo particles, in different proportions, was evaluated against biodeterioration organisms - fungi and termites.

\section{MATERIAL AND METHODS}

\section{Particleboard manufacturing}

Particleboards were produced in five different proportions of wood (Eucalyptus grandis W. Hill ex Maiden), rice husk (Oryza sativa L.) and bamboo (Bambusa vulgaris Schr.) particles, as shown in table 1. Six particleboards were manufactured for each treatment, in a total of 30 . The manufacturing parameters were: $0,65 \mathrm{~g} / \mathrm{cm}^{3}$ nominal density; $3,0 \mathrm{~N} / \mathrm{mm}^{2}$ pressing strength; 8 -minute pressing period; 40 -second pressing shutdown; $8 \%$ adhesive (urea-formaldehyde) and $1 \%$ wax based on the content of solids, in both cases considering particles mass loss.

Table 1. Proportion of particle type for each treatment.

\begin{tabular}{cccc}
\hline \multirow{2}{*}{ Treatment } & \multicolumn{3}{c}{ Proportion } \\
\cline { 2 - 4 } & $\begin{array}{c}\text { Wood } \\
\text { (Eucalyptus grandis })\end{array}$ & $\begin{array}{c}\text { Bamboo } \\
(\text { Bambusa vulgaris })\end{array}$ & $\begin{array}{c}\text { Rice husk } \\
(\text { Oryza sativa })\end{array}$ \\
\hline W & 100 & - & - \\
B & - & 100 & - \\
R & - & - & 100 \\
WB & 50 & 50 & - \\
WR & - & 50 & 50 \\
\hline
\end{tabular}

$\mathrm{W}=$ wood particles; $\mathrm{B}=$ bamboo particles; $\mathrm{R}=$ rice husk particles.

\section{Choice feeding assay with subterranean termites}

The assays were conducted according to methodology proposed by Supriana (1985). Six samples with 7,5 $\mathrm{cm} \times 2,5 \mathrm{~cm}$ x $0,95 \mathrm{~cm}$ (length, width and thickness) were taken from each particleboard. Apart from these samples, specimens from Pinus sp. sapwood, with the same dimensions, used as standard for comparison, were submitted to the assay as recommended by ASTM D - 3345 (1994).

Before the assay, the samples were placed in a climate chamber $\left(20^{\circ} \mathrm{C}\right.$ and $65 \%$ relative moisture $)$ until constant weight and weighed for determination of the initial mass for later comparison with the mass obtained at the end of the tests. The assay was set in a fibrocement box with a capacity of 250 liters, containing a 10$\mathrm{cm}$ sand layer with moisture adjusted to $75 \%$ of retention capacity. The samples were distributed according to a randomized block design, considering the five different proportions of particles besides the control samples (Pinus sp.). Even though, in these types of assays, it is recommended that the samples remain buried to half of their length, the probable difficulty in removing the samples after the assay, due to sand moisture, caused an adaptation in the methodology as suggested by Melo et al. (2010). Hence, the samples were placed horizontally on a metal tray, sitting on top of the sand. 
A Nasutitermes corniger Motsch. full colony (with all castes including king and queen) was placed inside a fibrocement box, disposed in a grid over the layer of humid sand and the metal tray with the samples. Afterwards, the fibrocement box was covered using a nylon screen in order to impede termite escape. The samples were exposed to termites for 45 days, in a climate-controlled room $\left(28^{\circ} \mathrm{C}\right.$ and $75 \%$ relative moisture). After the assay, the samples were again conditioned until the weights had stabilized $\left(20^{\circ} \mathrm{C}\right.$ and $65 \%$ relative moisture) and weighed in order to evaluate the percentage of mass loss.

\section{Accelerated decay test}

The Accelerated decay tests were conducted according to the methodology of ASTM D 2017 (2005). Six samples were taken from each panel in order to perform the tests, with $2,5 \mathrm{~cm} \times 2,5 \mathrm{~cm} \times 0,95 \mathrm{~cm}$ (length, thickness and width). After climatization $\left(20^{\circ} \mathrm{C}\right.$ and $65 \%$ relative moisture), the initial mass of each sample was obtained for later comparison with the final mass after the assay. Before exposing to fungi, the specimens were sterilized in autoclave at $127^{\circ} \mathrm{C}$ for 40 minutes.

Two species of xylophage fungi were used: the white rot Trametes versicolor (L.; Fr.) Pilat; and the brown rot Gloeophyllum trabeum (Pers.; Fr.) Karte. The assays were set up in clear glass flasks, with a wide opening, and a screwtop lid, capacity for $190 \mathrm{~mL}$, containing $70 \mathrm{~g}$ of sieved soil (2-mm mesh), free from coarse organic matter and with $\mathrm{pH}$ and moisture adjusted to 6,0 and $130 \%$ of retention capacity, respectively. In each flask, on the soil, a feeder strip placed of Pinus sp. sapwood (for Gloeophyllum trabeum cultivation) or of Cecropia sp. (for Trametes versicolor cultivation), with dimensions of 3,5 cm x 2,9 cm x $3 \mathrm{~mm}$. At the same time, flasks were set up for control samples also using feeder strip of Pinus sp. and Cecropia sp. sapwood (ASTM D 2017 2005).

Then, the flasks were autoclaved at $127^{\circ} \mathrm{C}$ for 45 minutes and, after cooling, they were inoculated in each flask (pipetted) with $2 \mathrm{~mL}$ of the respective culture medium, containing the mycelium. Afterwards, the flasks were taken to the incubator $\left(26^{\circ} \mathrm{C}\right.$ and $70 \%$ relative moisture), until the mycelium completely covered the back plate (four weeks). After the feeder strip colonization, one specimen was placed added in each flask. Control samples of Pinus sp. and Cecropia sp. sapwood with the same dimensions were also submitted to fungal action.

The samples remained in contact with the fungi for 12 weeks, in the incubator, under the conditions already described. After this period, they were taken removed from the assay flasks and the adhered mycelium removed. The samples were again climatized and weighed as prior to the experiment.

\section{Analysis of the results}

The particleboard resistance to termite attack was assessed by mass loss (Table 2) and wear of the panels due to termite activity provoked by the termites (Table 3 ). The mean values observed for mass loss and wear were evaluated by analysis of variance with further comparison of means by Student's $T$ test $(\mathrm{p}<0,05)$. For decay resistance, the results were evaluated based on mass loss, and the classification as suggested by ASTM D 2017 (2005), shown in table 3. The decay values caused by fungi were assessed through factorial analysis, considering the following factors: type of particleboard, with five levels, and type of fungus, with two levels. The factors or their interaction when verified as significant by $\mathrm{F}$ test was then analyzed by Scott-Knott's test $(\mathrm{p}<0,05)$. 
Table 2. Evaluation of wood wear (ASTM D 3345, 1994).

\begin{tabular}{lc}
\hline Waste & Rating System \\
\hline Sound, surface nibbles permitted & 10 \\
Light attack & 9 \\
Moderate attack, penetration & 7 \\
Heavy & 4 \\
Failure & 0 \\
\hline
\end{tabular}

Table 3. Class of decay resistance to xylophagous fungi (ASTM D 2017, 2005).

\begin{tabular}{lcc}
\hline Class of Resistance & Mass Loss (\%) & Residual Mass (\%) \\
\hline Highly resistant (HR) & $0-10$ & $90-100$ \\
Resistant (R) & $11-24$ & $76-89$ \\
Moderately Resistant (MR) & $25-44$ & $56-75$ \\
Nonresistant (NR) & $>45$ & $>55$ \\
\hline
\end{tabular}

In addition the Decay Susceptibility Index (DSI) was estimated Curling and Murphy (2002). The index is a means to aiming at compare the intensity of attack for the different xylophagous organisms (Equation 1). The DSI average values were also assessed by factorial analysis, considering the factors: type of particleboard, with five levels; and the type of xylophage organism, with three levels. The factors or their interaction, when verified as significant by the F test, was then analyzed by Scott-Knott's test $(p<0,05)$.

$$
D S I=\frac{W L S}{W L C} \times 100
$$

Where:

DSI $=$ Decay Susceptibility Index; WLs $=$ mass loss of the samples; WLr $=$ mass loss of the control samples.

\section{RESULTS AND DISCUSSION}

\section{Termite resistance}

The analysis of the mass loss caused by $N$. corniger termites indicates that their attack happened almost exclusively to the particleboards with wood (W) and bamboo (B) particles or with their mixture (WB), whereas the highest resistance was observed for the particleboards made from rice husk (R) or by their combination with wood particles (WR) (Figure 1). The high resistance of particleboards manufactured with rice husk to termites was also verified by Melo (2009), who attributed this performance to the high content of carbon and inorganic components in the rice husk, a material that is difficult to digest termites. It is noteworthy that this assay regarded feeding preference, wherein wood particleboards were offered simultaneously to the termites, making them choose the most suitable food source among those offered. This type of assay, according to Supriana (1985), presents more realistic results since termites are selective/ discerning feeders in nature. Another advantage of the method is that it causes a lower level of stress to the insects, since they could stay in their nest and were not housed in flasks with just sand and with only one food source, as standardized by ASTM D 3345 (1994). 


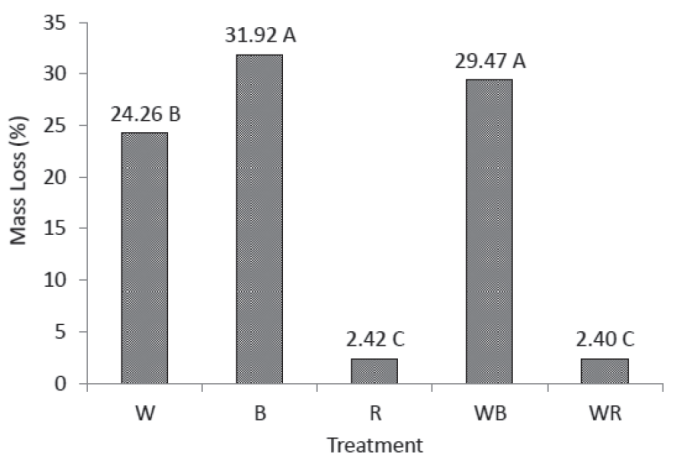

(a)

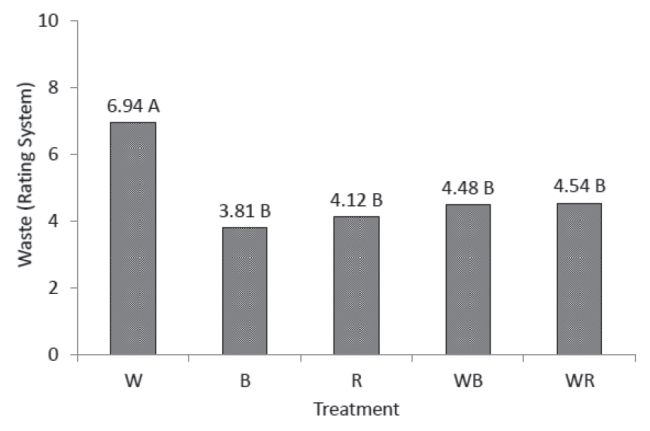

(b)

Figure 1. (a) Mass loss (b) waste caused by termites.

While comparing the resistance of B or WB particleboards with W particleboards, the highest resistance was verified for $\mathrm{W}$. This result can be explained owing to the fact that bamboo presents high starch content in its constitution, which makes it more susceptible to xylophagous organisms attack. Steiner et al. (2008) emphasizes that this high susceptibility is considered one of the main aspects limiting bamboo utilization as raw material for several purposes. However, Ubidia (2002) points out that this deficiency can be easily solved through treatments with preservative products.

It can still be observed in Figure 1 that the wear verified for the different particleboards was less evident in type W. For the other cases, no significant difference was verified. Although the particleboards made from rice husk showed lower mass loss, they also presented less resistance to handling after the assay, being those which most crumbled, with samples ending up totally uneven and, in some cases, with clear defects. This happened mainly due poor adhesion of the particles. This deficiency in adhesion was intensified by the assay condition with an environment of high relative moisture and by the low moisture resistance of the adhesive used (urea-formaldehyde). This explained the low grades assigned after the assay, not because of the termite attack, but due to the defects observed in the samples influenced by the deficient gluing.

The average mass loss observed for the control samples made with wood from Pinus sp. sapwood was $58,4 \%$ after to termite attack. 


\section{Decay resistance}

For both fungi, the decay class of the WR particleboards was moderately resistant and, for type R, resistant. On the other hand, W, B and WB particleboards showed different intensities of attack for the two fungi. T. versicolor showed the most severe attack. Only WB particleboards exposed to Trametes versicolor showed mass loss of over $45 \%$, being classified as nonresistant. For the other cases, the classification observed ranged from resistant to moderately resistant with - mass loss between $11 \%$ and $44 \%$ (Table 4). Teixeira et al. (1997) emphasize that the classification of moderately resistant, alone, does not derail these particleboards utilization, considering that they do not come to be used in adverse environments, such as outside or in direct contact with the soil.

Table 4. Comparison of average mass loss and classification of wood to fungi attack.

\begin{tabular}{cclll}
\hline \multirow{2}{*}{ Treatment } & \multicolumn{2}{c}{ Trametes versicolor } & \multicolumn{2}{c}{ Gloeophyllum trabeum } \\
\cline { 2 - 5 } & Mass Loss & \multicolumn{1}{c}{ Class of Decay } & Mass Loss & Class of Decay \\
\hline W & $31,8 \mathrm{cA}$ & Moderately Resistant & $21,0 \mathrm{bB}$ & Resistant \\
$\mathrm{B}$ & $44,0 \mathrm{aA}$ & Moderately Resistant & $20,5 \mathrm{bB}$ & Resistant \\
R & $23,4 \mathrm{dA}$ & Resistant & $18,6 \mathrm{bB}$ & Resistant \\
WB & $47,3 \mathrm{aA}$ & Nonresistant & $29,0 \mathrm{aB}$ & Moderately Resistant \\
WR & $41,5 \mathrm{bA}$ & Moderately Resistant & $31,0 \mathrm{aB}$ & Moderately Resistant \\
\hline
\end{tabular}

Averages in columns followed by the same lowercase letter, or in rows by the same capital letter do not differ
statistically (Scott-Knott, $\mathrm{p}>0,05$ ).

When submitted to T. versicolor (white rot) attack, the R particleboards were the most resistant, while types B and WB showed the lowest resistance. The highest resistance of particleboards made from rice husk can be attributed to the high silica content of this material, which confers higher durability and, therefore, resistance to microorganisms (Melo 2009). The high starch content in bamboo particles may have promoted the most severe attacks (Steiner et al. 2008). For G. trabeum (brown rot), the mixture of particles (WB and WR particleboards) was most severely attacked. No significant difference was observed for the other cases.

When the attack rates between the fungal species are compared, it is verified that in all cases $T$. versicolor caused the greatest damage. This result can be explained by the fact that white-rot fungi in general cause most severe attacks, with different effects for all the main wood chemical constituents - cellulose, polyoses and lignin. Nonetheless, brown-rot fungi, such as G. trabeum, are characterized by exclusively attacking the polysaccharide present in the lignocellulosic materials (Curling et al. 2000, Stangerlin et al. 2011).

The average mass loss found for control samples made of wood from Cecropia sp. sapwood and exposed to T. versicolor, as well as for those made of wood from Pinus sp. sapwood and exposed to G. trabeum was, respectively, $55,9 \%$ and $60,7 \%$. For both cases, mass loss was higher than the minimum required by ASTM D 2017 (2005), which is 50\%, showing that the fungus cultures were vigorous and that the experimental conditions were appropriate.

\section{Decay Susceptibility Index (DSI)}

The Decay Susceptibility Index (DSI) values obtained for the different types of particleboards studied are show in Table 5. DSI is a relative value, as it compares the sample mass loss to a reference species. Curling and Murphy (2002) recommend the use of this index to compare decay tests carried out in different laboratories, periods and conditions, or to compare samples of different sizes and densities. The principle of this analysis is based on the assumption of differences in the vigor of cultures, the incubation conditions or in characteristics of the materials. In the present study, the index was calculated to compare the attack between different types of decay fungi (white rot and brown rot) and the attack caused by termites. 
Table 5. Comparing between Decay Susceptibility Index (DSI) and the panels types for different xylophagous organisms.

\begin{tabular}{cccc}
\hline \multirow{2}{*}{ Treatment } & \multicolumn{3}{c}{ Decay Susceptibility Index (DSI) } \\
\cline { 2 - 4 } & Trametes versicolor & Gloeophyllum trabeum & Nasutitermes corniger \\
\hline $\mathrm{W}$ & $56,9 \mathrm{dA}$ & $34,6 \mathrm{cC}$ & $48,4 \mathrm{bB}$ \\
$\mathrm{B}$ & $78,7 \mathrm{bA}$ & $33,7 \mathrm{cC}$ & $54,6 \mathrm{aB}$ \\
$\mathrm{R}$ & $41,8 \mathrm{eA}$ & $30,7 \mathrm{cB}$ & $4,1 \mathrm{cC}$ \\
$\mathrm{WB}$ & $84,7 \mathrm{aA}$ & $47,8 \mathrm{bB}$ & $50,4 \mathrm{bB}$ \\
$\mathrm{WR}$ & $68,5 \mathrm{cA}$ & $55,4 \mathrm{aB}$ & $3,5 \mathrm{cC}$ \\
\hline
\end{tabular}

Averagens in columns followed by the same lowercase letter, or in rows by the same capital letter do not differ statistically (Scott-Knott, $\mathrm{p}>0,05$ ).

Averagens in columns followed by the same lowercase letter, or in rows by the same capital letter do not differ statistically (Scott-Knott, $\mathrm{p}>0,05)$.

In all cases, the experimental particleboards showed higher resistance than the reference woods, that is, DSI was lower than $100 \%$. Particleboards made only from rice husk (R) were most resistant of overall, particleboards manufactured with bamboo particles showed more intense deterioration. Comparing all three xylophagous agents, the particleboards were most susceptible to attack by the fungus T. versicolor.

\section{CONCLUSIONS}

The use of rice husk particles as raw material for particleboards provided the highest resistance to the evaluated xylophagous organisms. Particleboard made from bamboo had overall lower resistance. The Decay Susceptibility Index (DSI), used to compare the attacks of the different xylophage organisms, pointed to $T$. versicolor (white rot) as the fungus which caused the most severe attacks to the particleboards.

\section{REFERENCES}

American Society for Testing and Materials - ASTM. 1994. Standard method for laboratory evaluation of wood and other cellulosic materials for resistance to termites: specification ASTM D-3345. ASTM, Philadelphia.

American Society for Testing and Materials - ASTM. 2005. Standard method for accelerated laboratory test of natural decay resistance for woods: specification ASTM D - 2017. ASTM, Philadelphia.

Araújo, P.C.; Arruda, L.M.; Del Menezzi, C.H.S.; Teixeira, D.E. 2011. Lignocellulosic composites from Brazilian giant bamboo (Guadua magna) Part 1: Properties of resin bonded particleboards. Maderas: Ciencia Tecnología 13(3):297-306.

Curling, S.; Winandy, J.E.; Clausen, C.A. 2000. An experimental method to simulate incipient decay of wood by basidiomycete fungi. In: XXXI The International Research Group on Wood Preservation. Proceedings. Kona, IRG pp. 13 (IRG/WP/00-20200).

Curling, S.F.; Murphy, R.J. 2002. The use of the Decay Susceptibility Index (DSI) in the evaluation of biological durability tests of wood based board materials. European Journal of Wood and Wood Products 60(2):224-226. 
Evans, P.D.; Creffield, J.W.; Conroy, J.S.G. 2005. Natural durability and physical properties of particleboard composed of white cypress pine and radiata pine. Forest Products Journal 47(6):87-94.

Hiziroglu, S.; Jarusombuti, S.; Fueangvivat, V. 2005. Properties of bamboo-rice straw-eucalyptus composite panels. Forest Products Journal 55(12):221-225.

Kartal, S.N.; Green, F. 2003. Decay and termite resistance of medium density fiberboard (MDF) made from different wood species. International Biodeterioration Biodegradation 51(1):29-35.

Lee, H.H.; Kang, C.W. 1998. Development of rice hull insulation board using urea formaldehyde resin. Journal Korean Wood Science and Technology 26(4):50-55.

Melo, R.R. 2009. Physical-mechanical properties and decay resistance of wood and rice husk particleboard in different proportions (In Portuguese). Master's Thesis, Federal University of Santa Maria, Santa Maria, Brazil.

Melo, R.R.; Santini, E.J.; Haselein, C.R.; Garlet, A.; Paes, J.B.; Stangelin, D.M. 2010. Particleboard resistance to termite and fungi made with Eucalyptus grandis wood and different resins (in Portuguese). Cerne 16(3):82-89.

Okino, E.Y.A. 2007. Biodegradation of oriented strandboards of pine, eucalyptus and cypress exposed to four decay fungi (in Portuguese). Scientia Forestalis 74(1):67-74.

Shi, J.L.; Yang, D.Q.; Zhang, S.Y.; Riedl, B. 2006. Mold resistance of medium density fiberboard panels made from black spruce, hybrid poplar and a mixture of S-P-F chips. European Journal Wood and Wood Products 64(3):167-171.

Stangerlin, D.M.; Melo, R.R.; Garlet, A.; Gatto D.A. 2011. Natural durability of Eucalyptus grandis and Bambusa vulgaris particleboards under accelerated fungi decay test (in Portuguese). Ciência Rural 41(8):1369-1374.

Steiner, R.; Boahin, O.J.B.; Adu-Agyem, J. 2008. Development of a gas fired boiler for preservative treatment of sympodial bamboo species in Ghana. Journal of Bamboo Rattan 7(2):133-139.

Supriana, N. 1985. Notes the resistance of tropical wood against termites. International Research Group on Wood Preservation, Stockholm, Sweden (Doc. IRG /WP/ 1249).

Teixeira, D.E.; Costa, A.F.; Santana, M.A.E. 1997. Test for natural decay resistance of the sugar cane bagasse particleboard (in Portuguese). Scientia Forestalis 52(1):29-34.

Ubidia J.A.M. 2002. Traditional bamboo preservation in Latin America. Colour Max Publication, Los Angeles.

Yalinkilic, M.K.; Imamura, Y.; Takahashi, M.; Kalaycioglu, H.; Gokay, N.; Demirci, Z.; Ozdemir, T. 1998. Biological, physical and mechanical properties of particleboard manufactured from waste tea leaves. International Biodeterioration and Biodegradation 41(1):75-84.

Zabel, R.A.; Morrell, J.J. 1992. Wood microbiology: decay and its prevention. Academic, San Diego. 